\title{
Diagnosis dan Penatalaksanaan Striktur Esofagus
}

\author{
Fachzi Fitri, Novialdi, Wahyu Triana
}

\begin{abstract}
Abstrak
Latar belakang : Kasus striktur esofagus jarang ditemukan, namun kasus ini memerlukan penanganan yang optimal. Sebelum kita melakukan penatalaksanaan terhadap striktur esofagus, perlu dilakukan diagnosis yang akurat agar dapat memilih teknik penatalaksanaan yang tepat. Tujuan : untuk mengetahui cara mendiagnosis dan penatalaksanaan striktur esofagus. Tinjauan pustaka : Striktur esofagus merupakan penyempitan lumen esofagus yang dapat menyebabkan keluhan disfagia. Berdasarkan etiologinya, striktur esofagus dibedakan menjadi striktur esofagus benigna dan maligna. Striktur esofagus benigna disebabkan oleh GERD, zat korosif, web, radiasi, post anastomosis esofagus, sedangkan striktur esofagus maligna disebabkan oleh keganasan baik dari dalam maupun dari luar esofagus. Diagnosis suatu striktur esofagus dapat ditegakkan melalui pemeriksaan barium meal, esofagoskopi, tomografi komputer dan rontgen toraks. Penatalaksanaan kasus striktur ini dapat berupa dilatasi dengan busi atau balon, pemasangan stent dan terapi pembedahan. Pada kasus striktur esofagus maligna juga dapat dilakukan terapi laser dan teknik brakiterapi. Kesimpulan: diagnosis yang akurat perlu dilakukan sebelum memilih teknik penatalaksanaan yang tepat, sehingga dapat mengurangi keluhan disfagia pada penderita striktur esofagus.
\end{abstract}

Kata kunci: Striktur esofagus, barium meal, esofagoskopi, dilatasi, stent, laser, brakiterapi

\begin{abstract}
Background: Esophageal stricture is rare cases, but these cases required optimal management. Before we manage of esophageal strictures, need an accurate diagnosis in order to choose appropriate management techniques. Purpose: to know how to diagnose and management of esophageal strictures. Literature review: esophageal stricture is a narrowing of the lumen of the esophagus that cause dysphagia. Based on the etiology, esophageal strictures can be divided into benign and malignant. Benign esophageal strictures caused by GERD, corrosive substances, web, radiation, post-esophageal anastomosis, whereas malignant esophageal strictures caused by esophageal malignancy from inside or from outside of the esophagus. The diagnosis of esophageal stricture can be enforced through barium meal examination, esophagoscopy, computer tomography and thorax $X$-ray. Management of these strictures can be managed by the bougie or balloon dilatation, stent insertion and surgical technique. Malignant esophageal strictures can also be treated by laser therapy and brachytherapy techniques. Conclusion: Accurate diagnosis needs to be done before choosing the right management techniques that will reduce the complaints of dysphagia in patients with esophageal strictures.
\end{abstract}

Keywords: esophageal strictures, barium meal, esophagoscopy, dilatation, stents, laser, brachytherapy

Affiliasi penulis : Bagian Telinga Hidung Tenggorok Beah Kepala \& Leher Fakultas Kedokteran Universitas Andalas/ RSUP Dr. M. Djamil Padang

Korespondensi : Fachzi Fitri, Bagian Telinga Hidung Tenggorok Bedah Kepala Leher (THT-KL) Fakultas Kedokteran Universitas Andalas Padang. email: fachzifitri@gmail.com, Telp: 0751-810900

\section{PENDAHULUAN}

Striktur esofagus merupakan salah satu penyebab keluhan disfagia. Sekitar $30 \%$ keluhan disfagia ini disebabkan oleh penyempitan lumen esofagus. Disfagia adalah sensasi subjektif akan adanya abnormalitas organik selama pasase makanan cair atau padat dari rongga mulut ke lambung. Keluhan disfagia ini bervariasi mulai dari ketidakmampuan menelan (orofaringeal disfagia) sampai adanya sensasi terhambatnya makanan melewati esofagus sampai ke lambung (esophageal disfagia). ${ }^{1}$

Stiktur esofagus berdasarkan penyebabnya dapat dibagi menjadi striktur esofagus maligna dan benigna. Striktur esofagus maligna terutama disebabkan oleh keganasan pada esofagus, tapi juga dapat disebabkan oleh keganasan di luar esofagus sedangkan striktur esofagus benigna disebabkan oleh berbagai penyebab seperti Gastro Esophageal
Reflux Disease (GERD), zat kaustik/korosif, pasca anastomosis esofagus, pasca radiasi dan esofagitis kronis. ${ }^{2,3}$

Berdasarkan strukturnya, striktur esophagus dapat dibagi menjadi dua kategori yaitu striktur komplek dan striktur simpel. Striktur komplek merupakan striktur yang asimetris, irreguler, dengan diameter $<12 \mathrm{~mm}$ sedangkan striktur simpel adalah striktur yang simetris atau konsentrik dengan diameter $\geq 12 \mathrm{~mm}$. Striktur komplek sering disebabkan oleh keganasan, zat kaustik, pasca radiasi, pasca anstomosis esofagus dan GERD yang berat, sedangkan striktur simpel sering disebabkan oleh GERD yang ringan, Schatzki's ring atau web esofagus. $^{1,2}$

\section{DEFINISI}

Striktur esofagus merupakan penyempitan lumen esofagus karena terbentuknya fibrosis pada dinding esofagus, biasanya terjadi akibat inflamasi dan nekrosis karena berbagai penyebab. Stenosis esofagus adalah penyempitan lumen esofagus karena tumor atau penyebab lain. ${ }^{3}$

Dalam praktek sehari-hari sangat sulit dibedakan antara striktur dan stenosis ini, sehingga kedua istilah ini dipakai untuk semua penyempitan 
esophagus yang dapat menyebabkan gangguan menelan. $^{3,4}$

\section{Kekerapan}

Sampai akhir tahun 1980, terdapat sekitar $80 \%$ kasus striktur esofagus. Penyebab terbanyak yaitu GERD yang dikenal juga dengan peptic esophageal stricture. Insidennya mulai menurun seiring dengan berkembangnya penggunaan proton pump inhibitor (PPI) yang mulai dikeluarkan ke pasaran pada tahun 1989. Sekarang ini, striktur esofagus banyak disebabkan oleh keganasan, pasca pembedahan esofagus dan pasca radiasi. ${ }^{1,3}$

Di Amerika serikat, striktur esofagus ini banyak disebabkan oleh GERD yaitu sekitar $7-23 \%$ dari penderita GERD yang tidak diobati. ${ }^{5,6}$ Wienbeck $^{7}$ (1989) juga melaporkan bahwa insiden peptic esophageal stricture meningkat di Jerman yaitu sekitar 10-20\%. Mazzadi ${ }^{8}$ di Argentina (2004) melaporkan insidennya sekitar $0.8 \%$ dari seluruh pasien GERD dengan rata-rata umur 44-77 tahun dan lebih sering pada laki-laki dibanding wanita dengan rasio $2,7: 1$.

Di Indonesia selama 2 tahun (1988-1989) dari 858 pemeriksaan esofagoskopi, didapatkan 6 kasus striktur esofagus. Pada tahun 1994 dari 21 pemeriksaan endoskopi saluran cerna bagian atas, terdapat $6 \quad(28,57 \%)$ kasus striktur esofagus. Penyebab striktur tersebut adalah tumor esofagus $(14,29 \%)$ diikuti oleh bahan korosif $(9,25 \%)$ dan pasca skleroterapi varises esofagus $(4,76 \%){ }^{3}$

Di RS. Dr. M Djamil Padang, kasus striktur esofagus sangat jarang ditemukan. Selama 5 tahun terakhir (2006-2010) hanya ditemukan 6 kasus striktur esofagus.

\section{Anatomi dan fisiologi esofagus}

Esofagus adalah suatu tabung otot yang terbentang dari hipofaring (Cervikal 6) sampai ke lambung (Torakal 11) dengan panjang $23-25 \mathrm{~cm}$ pada dewasa. Esofagus pada awalnya berada di garis tengah kemudian berbelok ke kiri dan kembali ke tengah setinggi mediastinum (T7) kemudian berdeviasi ke kiri ketika melewati hiatus diafragma. Lengkungan esofagus dilihat dari sisi anteroposterior mengikuti lengkungan dari vertebra torakal. ${ }^{9}$

Perkembangan esofagus dimulai pada minggu keempat pembuahan, dimana pada minggu tersebut terbentuk suatu diverticulum laringotrakea pada bagian ventral dari foregut. Divertikulum tersebut terus berkembang ke arah kaudal kemudian akan dipisahkan dari tabung laringotrakea oleh septum trakeoesofageal. Rekanalisasi dari tabung esofagus ini terus berkembang sampai minggu ke delapan. ${ }^{10}$

Pada esofagus normal terdapat 3 penyempitan (gambar 1) yaitu pada pertemuan antara faring dan esofagus (Cervikal 6 atau $15 \mathrm{~cm}$ dari incisivus atas), pada persilangan arkus aorta dan bronkus kiri (Torakal 4-5 atau setinggi $25 \mathrm{~cm}$ dari incisivus atas) dan pada hiatus diafragma (Torakal 10 atau $40 \mathrm{~cm}$ dari incisivus atas). ${ }^{11}$ Lumen esofagus mempunyai diameter yang berbeda pada tiap-tiap lokasi serta mempunyai kemampuan elastisitas yang tinggi. Ukuran diameter lumen esofagus pada masing-masing penyempitan digambarkan pada tabel berikut (tabel 1). ${ }^{12}$

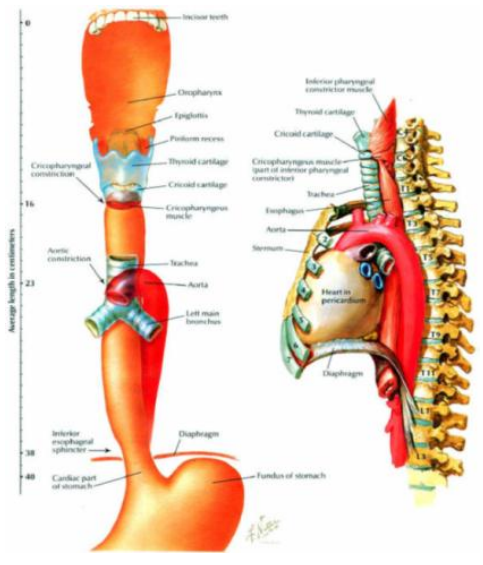

Gambar 1: Anatomi esofagus dan jarak penyempitan pada esofagus dari inscisivus atas. ${ }^{11}$

Tabel 1. Diameter Lumen Esofagus ${ }^{12}$

\begin{tabular}{lcc}
\hline Lokasi & $\begin{array}{c}\text { Diameter } \\
\text { Transversa } \\
(\mathbf{m m})\end{array}$ & $\begin{array}{c}\text { Diameter } \\
\text { AP } \\
(\mathbf{m m})\end{array}$ \\
\hline Krikofaring & 23 & 17 \\
Arkus aorta & 24 & 19 \\
Bronkus kiri & 23 & 17 \\
Diafragma & 23 & 23 \\
\hline
\end{tabular}

Dinding esofagus terdiri dari 4 lapisan dari dalam ke luar yaitu lapisan mukosa, submukosa, lapisan otot dan lapisan fibrosa. Pada Lapisan mukosa terdapat epitel gepeng bertingkat tidak berkeratin, lapisan submukosa terdapat serabut kolagen yang tebal dan serabut elastin serta kelenjer mukus dan plexus Meissner. Lapisan otot terdiri dari otot polos dan otot lurik. Pada sepertiga atas esofagus terdapat otot lurik dan sepertiga bawah terdapat otot polos, sedangkan sepertiga tengah terdapat campuran otot polos dan otot lurik. Otot bagian dalam mempunyai serat sirkuler sedangkan bagian luar mempunyai serat longitudinal. Serat sirkuler pada bagian bawah esofagus menebal membentuk spingter kardia. Plexus Myentericus Auerbach terdapat di antara kedua lapisan otot ini. ${ }^{12}$

Esofagus diperdarahi oleh cabang tiroidea inferior dari trunkus tiroservikalis, aorta torakalis desenden, cabang gastrikus sinistra dari arteri celiac dan cabang phrenikus inferior sinistra dari aorta abdominal. Esofagus dipersarafi oleh serabut parasimpatis yang berasal dari nervus vagus dan serabut simpatis dari trunkus simpatikus. Aliran limfe dari esofagus segmen servikal, torakal dan abdominal, masuk ke kelenjer servikal dalam, kelenjer mediastinum posterior dan kelenjer gastrikus. $^{9}$

Fungsi esofagus selain sebagai saluran makan, juga dalam proses menelan. Terdapat 3 fase proses menelan yaitu fase oral (bucal), fase faringeal dan fase esophageal. Pada fase oral, makanan yang masuk ke dalam mulut dikunyah, dilubrikasi oleh saliva dan dirubah menjadi bolus kemudian didorong masuk ke faring dengan bantuan elevasi lidah ke palatum. Fase faringeal dimulai bila bolus makanan ini telah berkontak dengan mukosa faring. Adanya reflek akan mendorong bolus memasuki orofaring, laringofaring dan terus ke esofagus. Pada saat ini 
hubungan ke nasofaring, rongga mulut dan laring akan tertutup. ${ }^{9}$

Setelah makanan masuk ke esofagus, spingter atas esofagus akan tertutup dan dengan gerakan peristaltik akan mendorong bolus makanan ke bawah. Sebelum peristaltik ini sampai di bagian bawah esofagus, spingter bawah akan berelaksasi sehingga dapat menyebabkan lewatnya cairan ke lambung. Gerakan peristaltik pada bagian bawah esofagus akan mendorong bolus makanan ke lambung kemudian menutup spingter bawah esofagus, fase ini disebut fase esofageal. Spingter atas esofagus berfungsi dalam proses menelan sedangkan spingter bawah berfungsi mencegah terjadinya refluks cairan lambung ke esofagus. ${ }^{9}$

\section{Etiologi}

Striktur esofagus dapat terjadi kongenital atau didapat. Hal ini disebabkan oleh kerusakan pada dinding esofagus yang diikuti oleh penebalan lapisanlapisan dinding esofagus dan terbentuknya jaringan parut. $^{13}$

Striktur esofagus kongenital disebut juga stenosis esofagus kongenital. Insidennya sangat jarang, hanya 1:25.000-50.000 kelahiran hidup. Kondisi ini diperkirakan akibat abnormalitas perkembangan embriogenik dari kanalisasi esofagus yang disebabkan oleh anoksia intrauterin. Gejala kliniknya sudah terlihat pada bayi baru lahir berupa disfagia, muntah dan adanya aspirasi pneumoni. ${ }^{14}$ Kelainan ini dapat juga disertai dengan fistula trakeoesofagus dan atresia esofagus. Terdapat 3 tipe histologi dari stenosis esofagus kongenital yaitu (1) penebalan fibromuskuler, (2) Cartilaginous ring, dan (3) membranous web. ${ }^{15}$

Striktur esofagus yang didapat terbagi menjadi dua yaitu striktur esofagus benigna dan maligna. Penyebab striktur esofagus benigna yang tersering adalah peptic esophageal striktur (70-80\%) sedangkan striktur maligna paling sering disebabkan oleh keganasan esofagus terutama Squamous sel karsinoma dan adenokarsinoma. ${ }^{3,5,16}$

Menurut Wang $\mathrm{YG}^{17} \mathrm{dkk}$ (2002) yang melakukan penelitian terhadap 55 pasien striktur esofagus yang akan dilakukan dilatasi, didapatkan 25 pasien dengan striktur esofagus benigna dan 30 pasien dengan striktur maligna. Penyebab striktur esofagus benigna terbanyak adalah post anastomosis striktur sedangkan striktur esofagus maligna terbanyak disebabkan oleh keganasan pada esofagus bagian tengah.

\section{Patogenesis}

Peptic esofageal sricture merupakan salah satu komplikasi jangka panjang dari GERD. ${ }^{8}$ Sekitar 40-65\% kasus GERD akan berkembang menjadi esofagitis erosif dan bila tidak diobati sekitar $4-23 \%$ esofagitis erosif ini akan berkembang menjadi striktur esofagus. $^{6}$

Faktor predisposisi terbentuknya striktur ini tidak begitu jelas, tapi beberapa studi menerangkan bahwa peptic esophageal stricture dapat terjadi pada refluks yang lama, adanya kelainan motilitas esofagus dan tekanan spingter bawah esofagus yang rendah. Striktur ini akan terbentuk bila inflamasi telah meluas ke seluruh lapisan esofagus (panmural inflammation). Lokasi striktur biasanya terdapat pada bagian distal esofagus (97\%), pada squamocolumnar junction dan hanya $3 \%$ yang terdapat pada bagian tengah esofagus. 6

Caustic esophageal stricture disebabkan tertelannya zat korosif pada anak-anak atau dewasa. Penyebab tersering adalah tertelan basa kuat dan asam konsentrasi tinggi. Luas dan beratnya kerusakan tergantung pada jenis zatnya, jumlah, konsentrasi, bentuk fisik zat dan lamanya kontak zat tersebut dengan mukosa esofagus. ${ }^{18}$ Striktur ini dapat terjadi pada bagian atas, tengah dan bawah esofagus atau di sepanjang esofagus bahkan dapat terjadi multipel. Lokasi caustic esophageal stricture yang paling sering menurut Paul dan Juhl (1972) dan Sutton (1969) yang dikutip dari Smith HS adalah pada tempat persilangan esofagus dengan bronkus utama kiri dan pada bagian bawah esofagus. ${ }^{19}$ Striktur esofagus ini dapat terjadi dalam 6 minggu sampai 10 bulan setelah tertelan zat korosif. ${ }^{20}$

Striktur esofagus maligna dapat terjadi pada semua bagian esofagus dan paling sering terjadi di bagian distal lalu diikuti bagian tengah dan proksimal. Keganasan esofagus ini dapat berasal dari lapisan mukosa, submukosa atau bisa juga disebabkan oleh metastase keganasan di luar esofagus. Keganasan mukosa paling sering berupa karsinoma sel skuamosa dan hanya sebagian kecil adenokarsinoma. Metastase keganasan di luar esofagus dapat berasal dari paru, payudara dan ovarium. ${ }^{2,3}$

\section{Manifestasi klinis}

Disfagia merupakan gejala yang utama dari striktur esofagus. Pada umumnya pasien mengeluhkan kesulitan menelan makanan padat. Lamanya disfagia, progresivitasnya dan ada atau tidaknya keluhan yang menyertainya seperti penurunan berat badan dan perdarahan, harus turut dievaluasi. $^{16}$

Lamanya disfagia juga dapat digunakan sebagai parameter klinik dalam membedakan striktur maligna dan benigna, dimana pada striktur maligna disfagia biasanya terjadi akut, progresif dan disertai dengan penurunan berat badan sedangkan pada striktur benigna disfagia terjadi kronik, intermiten dan tidak progresif. ${ }^{21}$

Selain disfagia, juga ditemukan keluhan heartburn pada $75 \%$ penderita peptic stricture. Selain itu juga ditemukan odinofagia, impaksi makanan dan nyeri dada.,

\section{Diagnosis}

\section{Barium Meal}

Pemeriksaan barium meal memegang peranan penting dalam mendeteksi adanya striktur esofagus. Pemeriksaan ini dapat memberikan informasi mengenai lokasi striktur, panjang dan diameternya serta keadaan dinding esofagus. Disamping itu pemeriksaan ini juga dapat menunjukan adanya kelainan-kelainan pada esofagus seperti divertikulum dan hernia esofagus. Pemeriksaan ini memiliki sensitivitas $100 \%$ pada striktur dengan diameter kurang dari $9 \mathrm{~mm}$ dan $90 \%$ pada striktur yang lebih dari $10 \mathrm{~mm} .^{5,21}$

Pemeriksaan barium meal menggunakan kontras barium sulfat yang dapat berupa cairan atau tablet. Tablet barium berukuran $12 \mathrm{~mm}$, bila terjadi retensi tablet barium di atas lokasi striktur dapat menunjukan bahwa striktur tersebut berukuran 
kurang dari $12 \mathrm{~mm} .^{21}$

Untuk mendeteksi adanya striktur esofagus digunakan biphasic esophagography yang terdiri dari double-contrast dan single-contrast. Singlecontrast bertujuan mengoptimalkan peregangan esofagus sehingga dapat dengan mudah mendeteksi striktur, sedangkan double-contrast dapat mengoptimalkan visualisasi mukosa esofagus terhadap adanya kelainan-kelainan seperti nodul, ulkus dan kelainan lain yang berhubungan dengan striktur. Pemeriksaan ini dapat juga dilakukan dengan bantuan digital fluoroskopi terutama striktur yang terdapat pada segmen servikal atau torakal atas esofagus yang sulit dilihat dengan teknik radiologi biasa karena sangat cepatnya pasase bolus makanan di daerah tersebut. ${ }^{21}$

\section{Esofagoskopi}

Pemeriksaan ini penting untuk mendiagnosis striktur esofagus. Pada pemeriksaan ini, mukosa lumen dapat diobati secara seksama dan bila ada kecurigaan keganasan dapat dilakukan biopsi untuk pemeriksaan histopatologi. ${ }^{3}$

Dalam literatur gastroenterologi dikatakan bahwa striktur esofagus sebaiknya didiagnosis dengan pemeriksaan endoskopi dan biopsi, karena sulitnya membedakan striktur benigna dan maligna melalui pemeriksaan radiologi saja sedangkan menurut literatur radiologi mengatakan bahwa striktur esofagus yang hanya memperlihatkan lesi jinak pada pemeriksaan esofagografi, hampir tidak pernah menunjukan adanya tumor ganas, oleh karena itu pemeriksaan endoskopi dan biopsi sebaiknya hanya dilakukan pada gambaran lesi yang kurang jelas atau dicurigai ganas. ${ }^{21}$

Untuk mendapatkan hasil pemeriksaan esofagoskopi yang baik sebelum dilakukan pemeriksaan, pasien tidak hanya dipuasakan minimal 6 jam tetapi juga dilakukan bilasan esofagus dengan air putih atau $\mathrm{NaCl}$ fisiologis melalui selang nasogastrik (NGT). ${ }^{3}$

Bila pada pemeriksaan esofagoskopi ditemukan lumen yang menyempit dengan mukosa yang tidak rata dan hiperemis, menandakan suatu esofagitis, sedangkan bila mukosanya irregular atau berbenjol-benjol disebabkan oleh keganasan. ${ }^{3}$

\section{Tomografi Komputer}

Baru-baru ini pemeriksaan tomografi komputer juga dipilih untuk mengevaluasi traktus gastrointestinal bagian atas karena bersifat noninvasif, cepat, akurat dan aman. Modalitas ini umumnya digunakan untuk menentukan ukuran dan metastasis dari tumor ganas esofagus. ${ }^{22}$

Ryu $\mathrm{HH} \mathrm{dkk}^{22}$ dalam studinya menggunakan tomografi komputer torakoabdominal pada kasus caustic stricture, untuk menilai derajat kerusakan esofagus dengan CT grading System dan menghubungkannya dengan striktur. CT grading system ini dapat dibagi menjadi 4 kelompok berdasarkan ketebalan dinding esofagus dan invasinya ke organ-organ yang berdekatan. Derajat kerusakan esofagus yang berhubungan dengan striktur adalah derajat III dan IV. ${ }^{22}$ Klasifikasinya dapat dilihat pada tabel berikut. (tabel 2)
Tabel 2. CT Grading System ${ }^{22}$

\begin{tabular}{|c|c|}
\hline Derajat & Penemuan TK \\
\hline $\mathrm{I}$ & $\begin{array}{l}\text { Penebalan dinding esofagus yg } \\
\text { tidak pasti }(<3 \mathrm{~mm})\end{array}$ \\
\hline II & $\begin{array}{l}\text { Edema pada dinding esofagus }(>3 \\
\mathrm{mm} \text { ) tanpa infiltrasi jaringan lunak } \\
\text { periesophageal. }\end{array}$ \\
\hline III & $\begin{array}{l}\text { Edema dinding esofagus dengan } \\
\text { infiltrasi jaringan lunak } \\
\text { periesophageal dan batas-batas } \\
\text { jaringan masih jelas }\end{array}$ \\
\hline IV & $\begin{array}{l}\text { Edema pada dinding esofagus dgn } \\
\text { infiltrasi jaringan periesofagus, } \\
\text { batas-batas jaringan tidak jelas } \\
\text { serta terkumpulnya cairan di sekitar } \\
\text { esofagus dan aorta desenden }\end{array}$ \\
\hline
\end{tabular}

\section{Rongent Toraks PA dan Lateral}

Pemeriksaan ini digunakan sebagai tambahan pada kasus striktur esofagus yang kita curigai akibat adanya penekanan massa dari luar esofagus. ${ }^{5}$

\section{Diagnosis Banding}

Berdasarkan gejala yang ditimbulkannya, striktur esofagus ini dapat dibedakan dengan akalasia, skleroderma dan miastenia gravis. ${ }^{3}$

\section{Penatalaksanaan}

Penatalaksanaan striktur esofagus ini secara garis besar dikelompokan menjadi penatalaksanaan striktur benigna dan penatalaksanaan striktur maligna. ${ }^{2}$

\section{Striktur Esofagus Benigna}

\section{Dilatasi}

Penatalaksanaan striktur esofagus benigna yang utama yaitu dilatasi. Dilatasi endoskopi muncul pertamakali pada abad ke-16, dimana para dokter menggunakan sebuah tongkat lilin untuk mendilatasi esofagus. Kata busi diambil dari kata Boujiyah, sebuah kota di Algeria yang merupakan pusat penjualan lilin. ${ }^{5}$

Tujuan utama dilakukannya dilatasi esofagus adalah untuk meringankan gejala striktur esofagus, pemberian nutrisi oral dan menurunkan resiko aspirasi pneumoni. Disamping itu dilatasi juga berguna untuk gastroskopi diagnostik bila endoskop tidak mampu melewati striktur serta untuk membantu pemasangan stents esofagus. $^{2}$

Kontraindikasi absolut dari dilatasi esofagus ini adalah perforasi esofagus karena ini dapat memperbesar defek dan menyebabkan mediastinitis sedangkan kontraindikasi relatif adalah adanya penyakit kardiorespiratori yang berat dan kelainan pembekuan darah. ${ }^{22}$ Secara garis besar terdapat 2 jenis dilator yaitu: ${ }^{3,5,16}$

1. Dilator mekanik

Disebut juga dilator "push-type" atau "bougie". Ada beberapa jenis dilator mekanik yaitu dilator merkuri, dilator metal (eder Puestow) dan dilator Savary-Gilliard. Dilator 
merkuri ada 2 jenis yaitu busi Hurst (ujung bulat) dan busi Maloney (ujung runcing). Busi Maloney ini merupakan dilator yang paling sering digunakan. Dilator ini terbuat dari karet dan berisikan mercuri atau tungsten dengan berbagai ukuran dari 16F-60F.

Dilator metal (Eder Puestow) dimasukan melalui bantuan kawat pemandu, dapat digunakan pada striktur yang panjang dan sangat sempit dengan kontrol fluoroskopi. Savary-Gilliard merupakan dilator yang terbuat dari polivinil dengan saluran ditengahnya untuk kawat pemandu. Tersedia dari ukuran 15F-35F. Alat ini semi fleksibel sehingga menyenangkan pasien.

Prosedur dilatasi dilakukan dengan rawat jalan. Pasien dipuasakan 8 jam sebelum tindakan. Pasien dalam posisi duduk diberikan anestesi lokal yang disemprotkan ke tenggorok. Jika tersedia alat endoskopi, dapat dilakukan bersamaan atau dapat juga menggunakan bantuan fluoroskopi. Busi ini dipertahankan selama 20-30 menit. Teknik ini dilakukan 2 kali seminggu lalu 1 kali seminggu bila terdapat perbaikan disfagia. Selanjutnya dilakukan bila diperlukan. ${ }^{3,23}$

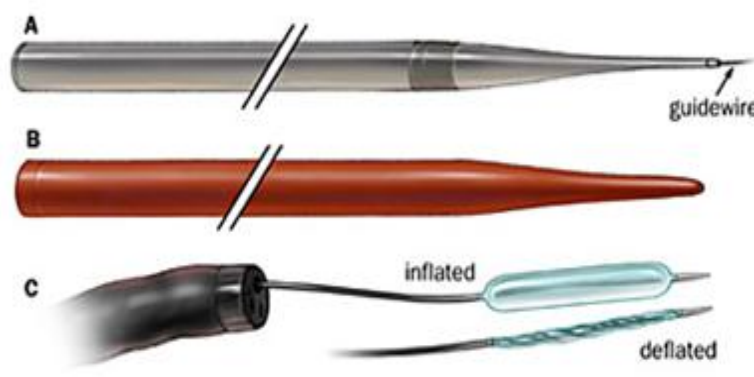

Gambar 2 : Dilator esophagus A. Savary, B. Maloney,C.Through The Scope (TTS) ballon kateter. $^{24}$

\section{Dilator balon}

Dilator balon ini masuk ke dalam esophagus dengan menggunakan panduan endoskopi, oleh karena itu disebut juga "Through The Scope" (TTS). Dilator ini tersedia dalam diameter dan panjang yang bervariasi dari 6-40 $\mathrm{mm}$. Dilatasi terjadi karena tekanan radial dari pengembangan balon.

Dilator balon dimasukan dengan panduan kawat pemandu melalui endoskopi. Setelah balon mencapai bagian striktur, balon dikembangkan dan dibiarkan selama maksimal 3 menit kemudian di kempeskan lagi. Prosedur ini diulangi dengan ukuran balon yang lebih besar. $^{23}$

Prosedur dilatasi esofagus adalah:, ${ }^{1,23}$

> Dilatasi ini dilakukan paling baik sampai ukuran diameter lumen esofagus 13-15 $\mathrm{mm}$.

> Dilator pertama yang dimasukkan, sebaiknya ukurannya sama dengan perkiraan ukuran diameter striktur esofagus.

$>$ Jangan memasukkan secara berurutan lebih dari 3 dilator dengan ukuran yang bertingkat. Dikenal dengan istilah "rule of three".

> Dilator mekanik digunakan pada striktur yang simpel, sedangkan dilator balon digunakan pada striktur komplek.

Komplikasi yang terjadi akibat dilatasi esofagus dapat berupa perforasi, bakteremia dan perdarahan. Perforasi sering terjadi pada striktur maligna $(6,4 \%$ dengan kematian $2,3 \%)$ dibandingkan dengan striktur benigna $(1,1 \%$ dengan kematian 0,5\%). Resiko perforasi ini juga dapat meningkat pada kasus striktur yang komplek. Perforasi ini kita curigai bila adanya keluhan nyeri dada yang persisten, sukar bernafas, demam dan takikardi. ${ }^{2,23}$ Komplikasi ini sebaiknya dikonfirmasi dengan pemeriksaan rontgen toraks dengan atau tanpa kontras. Pada rontgen toraks tanpa kontras akan terlihat pneumomediastinum, udara di bawah diafragma, pneumotoraks atau efusi pleura. Bila ada gejala klinis yang khas sedangkan rontgen toraks terlihat normal, belum bisa menyingkirkan adanya perforasi. Oleh karena itu sebaiknya dilakukan pemeriksaan rontgen toraks dengan kontras. ${ }^{23}$

\section{Kortikosteroid Intralesi}

Para ahli meneliti injeksi kortikosteroid pada striktur dapat mencegah terjadinya rekurensi disfagia. Injeksi ini dapat diberikan pada striktur yang kecil dan striktur yang berulang. ${ }^{2}$ Ramage $\mathrm{dkk}^{25}$ meneliti 30 pasien dengan peptic stricture yang berulang dilakukan dilatasi dengan balon dan injeksi triamcinolone $40 \mathrm{mg} / \mathrm{cm}^{3}$ pada 4 kuadran disekitar striktur. Hasilnya dibandingkan dengan prosedur dilatasi dengan balon saja. Hasil setelah follow up selama 1 tahun didapatkan pasien dengan injeksi kortikosteroid lebih sedikit rekurensinya dibandingkan dengan dilatasi balon saja.

\section{Stents}

Pemakaian stents pada kasus striktur esofagus benigna adalah sebagai paliatif terhadap keluhan disfagia dan untuk mencegah rekurensi striktur. SX.1.2tents ini dipasang dengan panduan endoskopi, terutama pada kasus striktur yang tidak mungkin dilakukan operasi. ${ }^{2,3}$

Komplikasi yang paling sering muncul pada pemasangan stents ini adalah terbentuknya jaringan granulasi akibat tekanan stents terhadap dinding esofagus. Pertumbuhan jaringan ini biasanya terjadi 2-6 minggu setelah pemasangan stents. Pertumbuhan jaringan ini dapat menyebabkan obstruksi berulang pada $40 \%$ pasien. $^{2}$

\section{Strikturoplasti}

Teknik ini dilakukan dengan bantuan endoskopi dan menggunakan pisau untuk membuat insisi pada 4 kuadran esofagus. Kemudian dilanjutkan dengan dilatasi esofagus menggunakan busi. ${ }^{5}$

\section{Reseksi Esofagus}

Prosedur reseksi esofagus dapat dilakukan pada kasus striktur benigna maupun maligna. Pemilihan teknik operasi tergantung pada jenis 

striktur, perluasan striktur dan adanya
komplikasi. $^{26}$

Reseksi esofagus adalah suatu operasi pengangkatan bagian lesi esofagus berikut dengan kelenjer limfenya dan kadang-kadang disertai juga oleh bagian lambung. Secara garis besar, reseksi esofagus ini dibagi menjadi esofagektomi dan esofagogastrektomi. ${ }^{27}$

Esofagektomi adalah suatu tindakan operasi pengangkatan bagian esofagus atau pengangkatan tumor ganas esofagus beserta kelenjer limfenya. Teknik ini dilakukan melalui 4 pendekatan insisi yaitu transtorakal, Ivor-Lewis (melalui sela iga ke-5), Three-hole esofagektomi (insisi kecil di dada dan abdomen) dan transhiatal (pada pertengahan abdomen). Operasi ini dilakukan dengan anestesi umum dan menggunakan endoskopi. ${ }^{27}$

Esofagogastrektomi adalah pengangkatan bagian bawah esofagus dan bagian atas lambung kemudian menyambungkannya. Teknik ini juga mengangkat kelenjer limfe yang ada di sekitarnya. Teknik ini dapat dilakukan secara terbuka dengan membuat insisi yang besar atau dengan bantuan laparaskopi. ${ }^{27}$

\section{Operasi Penarikan lambung (Gastric Pull-Up)}

Operasi penarikan lambung adalah suatu tindakan mentransposisikan lambung untuk tetap menjaga kesinambungan saluran gastrointestinal. $^{28}$

Tindakan operasi ini lebih disukai karena lebih simpel, mudah dikerjakan dan komplikasinya juga lebih ringan. Menurut Thomas dan Dedeo dikutip Hashish ${ }^{29}$ melaporkan bahwa operasi penarikan lambung lebih disukai dibandingkan operasi interposisi kolon karena operasi ini mempunyai satu anastomosis, suplai pembuluh darah lebih baik dan komplikasinya juga lebih ringan seperti terjadi leaks pada anastomosis dan striktur post anastomosis.

\section{Operasi substitusi esofagus (Esophageal replacement)}

Operasi substitusi esofagus dapat berupa interposisi kolon atau jejunum. Interposisi kolon atau jejunum merupakan suatu tindakan bedah dengan menggunakan kolon atau jejunum sebagai tandur untuk mensubstitusi esofagus. Tandur dapat menggunakan kolon ascenden, tranversum atau desenden., 30

Komplikasi yang terjadi lebih berat dibandingkan operasi penarikan esofagus. Anastomostic leaks dapat terjadi sekitar 48\% kasus, striktur post anastomosis $30 \%$ dan terbentuknya fistula $30,8 \%{ }^{29,30}$

\section{Striktur Esofagus Maligna}

Pada striktur esofagus maligna, tujuan terapi adalah untuk mengatasi masalah disfagia yang disebabkan oleh tumor. Terapi pembedahan merupakan terapi utama pada striktur esofagus maligna. Terapi ini dilakukan pada tumor yang belum bermetastasis baik lokal maupun regional. Prosedur lain yang biasa digunakan adalah pemasangan stents, terapi laser dan brakiterapi. $^{2}$

\section{Stents}

Pemasangan stents pada striktur esofagus maligna merupakan terapi paliatif terhadap disfagianya. Umumnya dilakukan pada tumor yang berlokasi di bagian tengah dan distal esofagus, sedangkan tumor yang berlokasi di bagian proksimal agak sulit dilakukan, karena sulitnya penempatan stents dan tingginya resiko komplikasi yang bisa ditemukan seperti perforasi, aspirasi pneumoni dan seringnya pasien mengeluhkan nyeri serta adanya sensasi benda asing. $^{2}$

Komplikasi akibat pemasangan stents pada striktur esofagus maligna sering terjadi disfagia berulang karena terjadinya migrasi stents dan tumbuhnya jaringan granulasi di sekitar stent. ${ }^{2}$

\section{Terapi Laser}

Pada beberapa pusat pengobatan telah mencoba dilatasi striktur esophagus dengan laser terutama sebagai terapi paliatif pada striktur maligna.3 Terapi laser ini dapat mengatasi keluhan disfagia pada sekitar $70 \%$ pasien dengan striktur esophagus. Terapi ini dilakukan untuk mempertahankan patensi lumen esophagus dengan cara memasukan laser ke dalam lumen esophagus dengan bantuan endoskopi. Pada awalnya terapi dilakukan 2-3 kali seminggu sampai keluhan disfagia hilang. ${ }^{31,32}$

Kontraindikasi terapi ini yaitu pada tumor yang telah berinfiltrasi ke jaringan sekitar atau bila terdapat fistula esophagus. Komplikasi yang dapat terjadi berupa perforasi $(2,3 \%){ }^{32}$

\section{Brakiterapi}

Brakiterapi dilakukan dengan menggunakan aplikator yang panjangnya $10 \mathrm{~mm}$ dan dimasukkan ke dalam esofagus dengan bantuan kawat pemandu. Sumber brakiterapi yang tersering digunakan adalah iridium (192/r). Prosedur ini dapat dilakukan dengan rawat jalan. Keluhan disfagia dapat diatasi dengan memberikan dosis 7,5-20 Gy yang dibagi menjadi 1-3 fraksi. $^{2}$

Komplikasi pasca brakiterapi jarang dilaporkan, dapat berupa pembentukan fistula pada esofagus, nyeri retrosternal dan esofagitis radiasi. Disfagia berulang pasca brakiterapi terdapat pada $10-40 \%$ pasien, umumnya disebabkan karena persistensi tumor atau rekurensi tumor. $^{2}$

\section{Prognosis}

Prognosis striktur esofagus tergantung pada penyebab utama dari striktur tersebut. Pada kasus peptic stricture yang disebabkan oleh refluks dari asam lambung ke esofagus, prognosisnya sangat baik bila dilakukan dilatasi striktur dan pemberian obat anti-refluks. ${ }^{5}$ Begitu juga pada kasus caustic stricture angka keberhasilannya setelah dilakukan dilatasi mencapai $60-80 \%$. Selain dilatasi, pada kasus caustic stricture ini juga dapat dilakukan terapi substitusi esofagus. ${ }^{18}$

Pada kasus keganasan esofagus, sebagian ditatalaksana dengan pembedahan dan sebagian lagi dengan medikamentosa. Terapi reseksi esofagus merupakan terapi pilihan utama pada kasus keganasan esofagus, terutama bila tumor masih 
berada pada stadium awal dan belum bermetastasis. Pemilihan terapi ini tergantung pada stadium tumor, keadaan umum pasien dan faktor resiko yang ada pada pasien tersebut. ${ }^{27}$ Sekitar $50 \%$ kasus tidak bisa dilakukan reseksi karena telah terdapat metastasis ke jaringan sekitarnya. Survival rate selama 5 tahun hanya $20 \%$.

\section{KESIMPULAN}

1. Striktur esofagus adalah penyempitan lumen esofagus yang menyebabkan 30\% keluhan disfagia.

2. Berdasarkan etiologinya, dapat dibedakan menjadi striktur esofagus benigna dan maligna

3. Berdasarkan strukturnya, dibedakan menjadi striktur komplek (asimetris, irreguler dan diameter $<12 \mathrm{~mm}$ ) dan striktur simpel (simetris dan diameter $\geq 12 \mathrm{~mm}$ )

4. Dulu GERD merupakan penyebab striktur esofagus terbanyak, seiring dengan berkembangnya penggunaan $\mathrm{PPI}$ penyebab terbanyak sekarang ini adalah keganasan, post anastomosis dan post radiasi.

5. Disfagia merupakan keluhan utama pada striktur esofagus, perlu dievaluasi lamanya keluhan, progresivitasnya dan gejala penyertanya untuk membedakan jenis striktur.

6. Pemeriksaan barium meal merupakan pemeriksaan utama dalam mendiagnosis suatu striktur esofagus dan dapat memberikan informasi mengenai lokasi, panjang dan diameter striktur serta keadaan dinding esofagus. Pemeriksaan ini memiliki sensitivitas $100 \%$ pada striktur $<9 \mathrm{~mm}$ dan $90 \%$ pada striktur $>10 \mathrm{~mm}$.

7. Pemeriksaan endoskopi dan biopsi sebaiknya hanya dilakukan pada lesi yang kurang jelas atau dicurigai ganas.

8. Dilatasi merupakan teknik penatalaksanaan utama pada striktur esofagus benigna yang bertujuan untuk meringankan keluhan disfagia dan dapat dikombinasikan dengan pemberian kortikosteroid intra lesi untuk mencegah rekurensi.

9. Pemasangan stent bertujuan sebagai terapi paliatif terhadap keluhan disfagia dan untuk mencegah rekurensi striktur.

10. Reseksi esofagus dapat dilakukan pada kasus striktur esofagus banigna maupun maligna dan terdapat dua jenis reseksi esofagektomi dan esofagogastrektomi. Pada kasus striktur maligna, reseksi hanya dilakukan pada stadium awal atau tumor yang belum bermetastasis.

11. Prognosis striktur esofagus tergantung pada penyebab utama striktur. Pada striktur benigna prognosisnya baik setelah dilakukan dilatasi 60 $80 \%$ ) sedangkan pada striktur maligna, prognosis tergantung pada stadium tumor, keadaan umum pasien dan faktor resiko yang ada pada pasien tersebut.

\section{DAFTAR PUSTAKA}

1. Monkemuller K, Kalauz M, Fry LC. Endoscopic Dilation of benign and malignant esophageal strictures. Gastrointest Endosc 2010, 27: 91-105

2. Siersema PD. Treatment option for Esophageal Strictures. Gastroenterology \& Hepatology 2008, 5(3):142-52.
3. Simadibrata M. Striktur/stenosis esofagus dalam: Buku Ajar Ilmu Penyakit Dalam. Interna Publishing: 5Th ed. Jakarta; 2009.p 493-6.

4. Gillson S. Esophageal strictures, c 2010 [Update 2010 Nov 17;cited 2011 Nov 6]. Available from: heartburn. about com/cs/articles/a/esoph stricture.htm.

5. Mukherjee S. Esophageal stricture. c2009 [update 2009 Dec 29; cited 2011 August.16]. Available from

http:/emedicine.medscape.com/article/175098

6. Thomas GR, Raynor T. Complete esophageal stenosis secondary to Peptic Stricture in the cervical esofagus: case report. ENT-Ear,Nose \& Throat Journal 2006, 85(3): 187-9

7. Wienbeck M, Barnet J. Epidemiology of reflux esofagitis. Scand J gastroenterol 1989,156 (suppl): 7-13.

8. Mazzadi SA, Garcia AO, Salis GB et al. Peptic esophageal stricture: a report from Argentina. Disease of the Esofagus 2004, 17: 63-6.

9. Gray's Anatomy of the Human Body. The Esofagus. c2009 [update 2009;cited 2011 sept 9]. Available from http://education.yahoo.com/reference/gray/subje cts/subject/245

10. Lamb PJ, Griffin SM. The anatomy and physiology of the oesophagus in: Jhon Lumley series editor. Upper Gastrointestinal Surgery. London: Springer; 2005. p1-15.

11. Witmer LM. Clinical anatomy and histology of the upper gastrointestinal system. c2003. [Update 2003 Jan 28; cited: 2011 Nov 10]. Available from: http://www.oucom.ohiou.edu/dbmswitmer/gs-rpac.htm

12. Yang YJ, Deutsch ES, Reilly JS. Bronchoesophagology in: Ballenger's otorhinolaryngology Head and neck surgery 16 th ed. Chicago: Bc Decker Inc 2003:p 1549-77

13. Bittencourt PFS, Carvalho SD, Ferreira AR et al. Endoscopic dilatation of esophageal strictures in children and adolescent. Journal de pediatria 2006, 82(2): 127-31.

14. Oh $\mathrm{CH}$, Levina MS, Katzka DA et al. Cogenital esophageal stenosis in adults: clinical and radiographic finding in seven patients. AJR 2001, 176: 1179-82.

15. Vasudevan SA, Kerendi $F$, Lee $H$ et al. Management of congenital esophageal stenosis. Journal of pediatric surgery 2002, 37(3): 1024-6

16. Khanna N. How do I dilate a benign esophageal stricture?. Can J Gastroenterol 2006, 20(3): 1535.

17. Wang YG, Tio TL, Soehendra N. Endoscopic dilation of esophageal stricture without fluoroscopy is safe and effective. World J Gastroenterol 2002,8(4): 766-8.

18. Rehman S, Hameed K, Khan IM. Endoscopic dilatation for caustic esophageal strictures.JPMI 2007, 21(4): 292-5.

19. Smith HS. Caustic strictures of the oesofagus. British Journal of radiology 1975, 48: 646-8.

20. Gupta DK, Srinivas M, Dave S. An epidemiological survey on corrosive esophageal strictures in children. J Indian Assoc Pediatr Surg 2003, 8: 80-5

21. Luedtke $P$, Levine MS, Rubesin SE et al. 
Radiologic diagnosis of benign esophageal strictures: A pattern approach. RadioGraphics 2003, 23: 897-909

22. Ryu HH, Jeung KW, Lee BK et al. Caustic injury: can CT grading system enable prediction of esophageal stricture?. Clinical Toxicology 2010, 48: 137-142.

23. Riley SA, Attwood SEA. Guidelines on the use of oesophageal dilatation in clinical practice. Gut 2004;53 (suppl I): il-i6.

24. Hopkin J. Gastroesophageaal Reflux Disease: Therapy. c 2001. [Update 2001: cited 2011 Nov 10]. Available from: http/www.hopkin-gi.org

25. Ramage Jr. A prospective, randomized, doubleblind, placebo-controlled trial of endoscopic steroid injection therapy for recalcitrant esophageal peptic strictures. Am J Gastroenterol 2005: 2419-25.

26. Kim SH, Lee KS, Shim YM et al. Esophageal resection: indications, techniques and radiologic assessment. RadioGraphics 2001, 21: 1119-40.

27. Fan V. Esophageal resection c 2011 [updated 2011; cited 2011 Oct 17]. Available from: http://www.Surgeryencyclopedia.com/Ce-
$\mathrm{Fi} /$ Esophageal-Resection. Html

28. Rezale J, Peyvandi H, Hallad-Mofrad HR, et al. gastric pull-up reconstruction for pharyngolaryngoesophagectomy in head and neck cancer and cervical esophageal squamous cell carcinoma.Acta Medica Iranica 2007; 45(6): 473-6.

29. Hashis A, Ismail K, Metwally MF, et al. Gastric pull-up versus colon interposition in treatment of corrosive esophageal stricture. Egyptian Journal of Surgery 2003; 22(3): 283-8.

30. Furst $H$, Hartl $W H$, Lohe $F$, et al. Colon interposition for esophageal replacement. Ann Surg 2000; 231(2): 173-8.

31. Herbella FA. Esophageal cancer treatment \& management. c 2011. [Update 2011 Sept 2; cited 2011 Dec 5]. Available from: emedicine, Medscape.com/article/277930-treatment.

32. P Mlkvy, P Makavnik, J Majek, et al. Laser \& Photodynamic therapy for esophageal cancer. St. Elizabeth Oncology Hospital 2003; 90-1.

33. Sharma P, Kozarek R. Role of esophageal stents in benign and malignant disease. ACG Practice Guidelines 2009, 105: 258-68. 